\title{
Correction to: Effect of cough assist device on blood gasses and period of mechanical ventilator for pneumonic children with general hypotonia
}

Raheel Sanad ${ }^{1 *}$, Shimaa Mohamed Refaat ${ }^{2}$, Bassant Meligy ${ }^{1}$ and Faten Hassan Abdelazeim²

Correction to: Bull Faculty Phys Ther 26, 31 (2021)

https://doi.org/10.1186/s43161-021-00049-5

Following the publication of the original article [1], the authors identified an error in the sequence of the authors.

The incorrect order is:

Raheel Sanad1*, Shimaa Mohamed Refaat2, Faten Hassan Abdelazeim2 and Bassant Meligy1

The correct order is:

Raheel Sanad1*, Shimaa Mohamed Refaat2, Bassant Meligy1 and Faten Hassan Abdelazeim2

The author group has been updated above and the original article [1] has been corrected.

Author details

${ }^{1}$ Cairo University Specialized Pediatric Hospital (CUSPH), Cairo, Egypt. ${ }^{2}$ Faculty

of Physical Therapy, Cairo University, Cairo, Egypt.

Published online: 16 February 2022

\section{Reference}

1. Sanad R, et al. Effect of cough assist device on blood gasses and period of mechanical ventilator for pneumonic children with general hypotonia. Bull Faculty Phys Ther. 2021;26:31. https://doi.org/10.1186/ s43161-021-00049-5.

The original article can be found online at https://doi.org/10.1186/s43161021-00049-5.

*Correspondence: raheelsanad679@gmail.com

${ }^{1}$ Cairo University Specialized Pediatric Hospital (CUSPH), Cairo, Egypt original author(s) and the source, provide a link to the Creative Commons licence, and indicate if changes were made. The images or other third party material in this article are included in the article's Creative Commons licence, unless indicated otherwise in a credit line to the material. If material is not included in the article's Creative Commons licence and your intended use is not permitted by statutory regulation or exceeds the permitted use, you will need to obtain permission directly from the copyright holder. To view a copy of this licence, visit http://creativecommons.org/licenses/by/4.0/. 